\title{
Regulation of Seal Animal Welfare Risk, Public Morals and Inuit Culture under WTO Law: Between Techne, Oikos and Praxis
}

\author{
Editor's Introduction
}

\begin{abstract}
Alexia Herwig*
The EC-Seals case raises a number of interesting issues for scholars researching in the broad area of risk regulation. This symposium addresses a selection of them through innovative, analytical contributions whose goals are to test central assumptions and question the logic of the findings and to bring fresh solutions to problems faced by the Appellate Body and the panel. In keeping with this analytical focus, this introduction to the symposium will not just present a summary of the key legal findings. Instead, it attempts to draw some further conclusions from the different contributions, to place the contributions in their broader legal context and to make connections between aspects (not) decided in Seals and scholarship on risk regulation, more generally.
\end{abstract}

\section{Introduction}

On 22 May 2014, the Appellate Body decided the appeal against several findings of the Panel Report in EC-Seals. ${ }^{1}$ The case concerned a European ban on seal and seal-containing products motivated by animal welfare and feelings of moral disapproval. ${ }^{2}$ Three exceptions to the ban applied. ${ }^{3}$ Seals hunted by Inuit with a tradition of seal hunting in the area could be placed on the market provided that the hunts contributed to their subsistence and that the seals were partly used, processed or consumed by that community in accordance with its traditions. Seals from non-systematic hunts for the purpose of

* Assistant Professor, University of Antwerp.

1 European Communities - Measures Prohibiting the Importation and Marketing of Seal Products, Report of the Appellate Body, WTO Doc., WT/DS400/R, WT/DS401/AB/R, 18 June 2014 and European Communities - Measures Prohibiting the Importation and Marketing of Seal Products, Report of the Panel, WT/DS400/R, WT/DS401/R.

2 Regulation (EC) No. 1007/2009 of the European Parliament and of the Council on trade in seal products, OJ 2009 L 286.

3 The exceptions are contained in Commission Regulation (EU) No. 737/2010 laying down detailed rules for implementation of the Basic Regulation, OJ 2010 L 216.

4 The total number of annual European MRM seals was less than 90.

$5 E C-$ Seals, Report of the Appellate Body, supra note 1, para. 5.334. protecting local fisheries and subject to a marine resources management plan could be placed on the market in the EU on a not-for profit basis. Travelers who had purchased seal products abroad were also allowed to bring back their purchases for personal use.

Both the ban and the Inuit (IC) and marine resources management (MRM) exceptions were contested. The effect of the ban and the exceptions was that virtually all seal exports from Greenland and virtually all domestically-hunted seals could be placed on the market of the EU under the IC and the MRM exception respectively. ${ }^{4}$ Norway could not export seals to the EU because its seals were commercially hunted, albeit in accordance with a marine resources management plan. The vast part of Canadian seal production was formally ineligible to be placed on the market because it derived from commercial hunts. Seals hunted by Canadian Inuit could in principle access the market of the EU under the IC exception. However, the Canadian Inuit seal hunts are small-scale hunts whose products were distributed through the commercial sealing industry. ${ }^{5}$ As a result of the ban, this commercial sealing industry could no longer export to the EU and even if it continued to distribute the Inuit seals, would have had to ensure segregation of Inuit and non-Inuit seal in its production facilities. 


\section{Techne: Is the Seals Regime a Technical Regulation?}

Interestingly, the Appellate Body and the panel approached the case from opposite angles. The panel made most of its finding under the Agreement on Technical Barriers to Trade (TBT) and then read most of them across to its analysis under the General Agreement on Tariffs and Trade (GATT). ${ }^{6}$ The Appellate Body reversed the panel's finding about the applicability of the TBT Agreement and declared those findings moot. ${ }^{7}$ Instead, it decided the case under the GATT.

The two agreements are potentially quite different. The conditions imposed by Article XX on public policies apply particularly strongly to the manner of application of the regulatory measure, where unjustified over- or under-regulation relative to the policy goal leads to a finding of an inconsistency (chapeau). ${ }^{8}$ Whether or not the regulatory measure is the least-restrictive of trade is also tested but most measures lose under the chapeau. Importantly, $\mathrm{Ar}$ ticle XX only comes into play once another GATT provision has been found to be violated. In contrast, the TBT Agreement contains a free-standing necessity obligation that does not hinge on a prior violation of another obligation. ${ }^{9}$ It also does not offer any general exceptions to justify violations, including of its non-discrimination provision. The difficult boundary drawing between the prevention of unjustified trade externalities and the preservation of regulatory autonomy of the WTO members has to be undertaken just in the obligation in the TBT Agreement. Unlike the GATT, the TBT Agreement contains an open-ended list of public policy objectives and it also creates a derogable obligation to use international standards as the basis for regulatory measures, going beyond the negative integration paradigm of the GATT. ${ }^{10}$ It thus seems fair to say that the focus of the TBT Agreement shifts somewhat more to regulation compared to the trade-focused GATT.

Both the contributions by Ming Du and by Robert Howse discuss the applicability of the TBT Agreement. The TBT Agreement only applies to technical regulations and standards, which must be documents laying down product characteristics or their related processing and production methods (PPMs). As Ming Du points out, the European seals regulations had a mixed characteristic. The ban prohibited com- posite products with certain characteristics, namely those of containing seal. The exceptions, which ultimately determined admission to the market, hinged on the way those seals were hunted and thus a PPM. Du's contribution critically examines the Appellate Body's finding that the measure has to be assessed as a whole and in relation to its essential features in order to decide on the applicability of the TBT Agreement. He takes issue with the Appellate Body's characterizing the exceptions as essential and asks whether the primary ban should not rather be seen as more essential. The question of whether or the TBT Agreement applies is also significant because the regulatory concerns of the EU look anything but technical. Robert Howse submits in his comment that the concerns of the EU can be classified as noninstrumental moral concerns and that the TBT Agreement does not apply to such non-instrumental moral concerns.

In spite of this intricate question relating to the applicable agreement, the outcomes of the decision under the GATT and under the TBT Agreement were substantially similar. The EU ban was considered to be the least-trade restrictive measure to take to protect public morals concerns under both agreements and the real inconsistency arose in relation to the chapeau and similar elements relevant under the TBT analysis of Article 2.1. ${ }^{11}$ This raises the additional question of whether or not the key TBT obligations of non-discrimination and necessity, as interpreted, really add anything to the corresponding GATT disciplines. Some have even wondered whether the TBT Agreement should not be abolished to save litigation cost. $^{12}$

6 The panel did not apply the TBT test of Art. 2.1 focusing on whether detrimental impacts stem exclusively from a regulatory distinction under its GATT analysis. EC-Seals, Report of the Panel, supra note 1, paras. 7.607-7.609.

7 EC-Seals, Report of the Appellate Body, supra note 1, para. 5.70

8 Lorand Bartels, "The WTO Legality of the Application of the EU's Emission Trading System to Aviation",23 European Journal of International Law (2012), pp. 429 et sqq, at p. 452.

9 TBT Agreement, Art. 2.2

10 TBT Agreement, Art. 2.4

11 EC-Seals, Report of the Appellate Body, supra note 1, paras. 5.279, 5.290, 5.320-5.339; EC-Seals, Report of the Panel, supra note 1, at paras. 7.302-7.319, 7.504.

12 Philip I. Levy and Donald H. Regan, 'EC-Seal Products (TBT Aspects of the Panel and Appellate Body Reports): Seals and Sensibilities, forthcoming in World Trade Review, available in draft on SSRN.com, p. 57 


\section{Oikos: The Appellate Body's view on market competition in Article III:4 of GATT 1994}

In Seals, the Appellate Body has now told us that the GATT and the TBT Agreement do diverge in their respective non-discrimination provisions. GATT Article III:4 prohibits less favourable treatment of imported products that compete closely with domestic products. Article I:1 of the GATT serves to prohibit discrimination between closely competitive imports inter se. Statements by the Appellate Body to the effect that less favourable treatment would require comparing the treatment of the group of imports and the group of domestic products, ${ }^{13}$ that a greater burden on imports unrelated to the foreign origin of the products would not violate Article III: $4^{14}$ and its TBT case law ${ }^{15}$ might suggest that greater burdens on imports due to regulatory policies would also be nondiscriminatory. In Seals, the Appellate Body has now clearly rejected this argument. ${ }^{16}$ In support of its conclusion, it pointed to the availability of a specific provision in the GATT dealing with the necessity and application of regulatory policies, the general exceptions in Article XX. ${ }^{17}$ The non-discrimination obligations in the GATT are about economic effects alone. In contrast, for the non-discrimination obligation in Article 2.1 of the TBT Agreement, the Appellate Body has held that greater burdens on imports stemming exclusively from a legitimate regulatory distinction are consistent with that obligation. ${ }^{18}$ The non-discrimination obligation in the TBT Agreement is

13 European Communities - Measures Affecting Asbestos and Asbestos-Containing Products, Report of the Appellate Body, WTI Doc., WT/DS135/AB/R, 12 March 2001, para. 100.

14 Dominican Republic - Measures Affecting the Importation and Internal Sale of Cigarettes, Report of the Appellate Body, WTO Doc., WT/DS302/AB/R, 19 May 2005, para. 96

15 United States - Measures Affecting the Production and Sale of Clove Cigarettes, Report of the Appellate Body, WTO Doc., WT/DS406/AB/R, 14 April 2012, paras. 175, 181-2; United States - Certain Country of Origin Labelling (COOL) Requirements, Report of the Appellate Body, WTO Doc., WT/DS384/AB/R, adopted 23 July 2012, paras. 271, 373-379, United States, Measures Concerning the Importation, Marketing and Sale of Tuna and Tuna Products, Report of the Appellate Body, WTO Doc., WT/DS381/AB/R, 13 June 2012, paras. 215, 315-322.

16 EC-Seals, Report of the Appellate Body, supra note 1, para. 5.117.

17 Ibid., paras. 5.121-5.125.

18 See case law cited at n. 15 supra.

19 EC - Seals, Report of the Appellate Body, supra note 1, para. 5.127-5.129. about economic effects and illegitimate or disproportionately wide regulatory policies.

The apparent result of the decision in Seals is that the kind of market competition to be protected under GATT Article III:4 and TBT Article 2.1 are different. The normal default market under the GATT is an unregulated market, whereas the default market under the TBT is perceived, as in institutional economics, as a market shaped and created by regulatory intervention. Put differently, under the GATT, (risk) regulation is the exception to laissez-faire economics while under the TBT, (risk) regulation is a normal companion of and on a par with free market forces.

This raises the question of why two agreements in pursuit of a shared objective of trade liberalization should operate with different conceptualizations of the market. If, legally speaking, the two agreements dealt with distinct subject matters, a different underlying concept of the market would have possibly made sense. This seems not to be the case, however. TBT measures are fully covered by the GATT and, as the Appellate Body has also told us, there is probably no difference in breadth of the available public policy exceptions under the GATT and the TBT. ${ }^{19}$ More fundamentally, it is difficult to imagine a market that is not in some sense the product also of regulation - be it contract laws, tort liability or money, including in their more specific application to distinct products that would not be marketable without heavy regulatory framing (e.g. medicines, hazardous chemicals).

Against this backdrop, the contribution by Herwig questions the conclusion from Seals that the default concept of the market underlying the GATT really is that of a laissez-faire market. She posits that the default market of the GATT should be seen as a perfect market, while Article XX should be construed as limited to market interventions necessary beyond dealing with externalities. The result would be that the TBT Agreement and the GATT worked in unison in their review of regulatory policies through the nondiscrimination provision, while a distinct sphere of application is preserved for GATT Article XX. As Robert Howse rightly points out in his comment, the suggested analysis would also imply that detrimental impacts due to market distortions in the export market should not give rise to a finding of less favourable treatment either. In the specific case of Seals, he points out that the Canadian commercial 
seal industry was essentially maintained in existence only thanks to Canadian subsidies.

\section{Oikos or praxis? The justifiability of the Inuit exception to the ban on seals and seal products.}

Surprisingly perhaps to the scholar in risk regulation, the Seals case was the first time a WTO panel and the Appellate Body were confronted with a regulatory scheme involving multiple cost-benefit trade-offs. When regulators take risk management decisions and determine the desired level of protection against a risk, they often engage in such complex analyses, including ones that comprise risk-risk trade-offs. This decision is a political decision and case law has repeatedly affirmed that the WTO members' determination of their level of risk tolerance is not reviewable. ${ }^{20}$ Measures based on an evaluation of multiple costs and benefits and those including exceptions to the primary policy goal are, in other words, the mainstay of regulation.

However, the panel and the Appellate Body struggled somewhat to assess the necessity of the Seals regime for the pursuit of its regulatory objectives. The necessity requirement is contained both in Article XX (a) of the GATT invoked by the EU in justification of the discriminatory treatment, and it is also an obligation under Article 2.2 of the TBT Agreement. In essence, the Panel as upheld by the Appellate Body found that IC and MRM exceptions reduced the contribution towards seal welfare and addressing related European public morals because there was no evidence that Europeans were concerned about the well-being of Inuit and the protection of local fish stock. ${ }^{21}$ It also refused to find that the exceptions added separate objectives for the purpose of the necessity analysis. ${ }^{22}$

As a result of this finding, regulatory policies with exceptions are harder to justify under the necessity analysis than those without exceptions. From the perspective of rational decision-making on risk, which can involve risk-risk trade-offs, this result seems unsatisfactory. ${ }^{23}$ Fitting additional objectives under the necessity analysis, however, is rendered difficult by the fact that the paragraphs of Article XX speak of necessity in relation to a specific, single policy objective and seem to imply interest balancing between that objective and trade liberalization concerns only.
Regan has, however, proposed that the regulator's indifference curve should guide the necessity analysis in cases of complex regulatory interest balancing with exceptions. When a different balance between the primary and secondary objective is less trade restrictive as well and on the same or a higher indifference curve of the regulator, it should be considered a less-trade restrictive, reasonably available alternative to him. ${ }^{24}$

Because the ban (with its exceptions) was nevertheless considered to fulfill the necessity requirement, the Appellate Body, following the sequence of analysis of Article XX, moved to consider the justification of the exceptions under the chapeau, where they ultimately failed the test because of possibly avoidable seal suffering in Inuit hunts and too much ambiguity in the exceptions, permitting a significant amount of commercial-type exports. ${ }^{25}$ As discussed by Petros Mavroidis, the Appellate Body departed from two prior decisions in its case law, firstly, that the chapeau was about the manner of application and not the design of measures and secondly, that the only type of discrimination acceptable under the chapeau was one rationally connected to the policy objective invoked to establish the necessity of the measure.

The Appellate Body's turn to the chapeau has attracted praise from commentators who consider the chapeau to be about discrimination and the paragraphs of Article XX to be about the measure's traderestrictiveness. ${ }^{26}$ However, as Petros Mavroidis' con-

20 EC-Asbestos, supra note 13, para. 168; Korea-Measures Affecting Imports of Fresh, Chilled and Frozen Beef, Report of the Appellate Body, WTO Doc., WT/DS161/AB/R, WT/DS169/1B/R, 10 January 2001, para. 176 and in the context of a public morals policy itself, United States - Measures Affecting the Cross-Border Supply of Gambling and Betting Services, WTO Doc., WT/DS285/R, 20 April 2005, para. 6.461.

21 EC-Seals, Report of the Appellate Body, supra note 1, paras. 5.217; EC-Seals, Report of the Panel, supra note 1, paras. 7. $445,7.447,7.451-2,7.453-7.455,7.460$ and 7.638.

22 EC-Seals, Report of the Panel, supra note 1, paras. 7.401, 7.402.

23 Alexia Herwig, "Too much Zeal on Seals? Animal Welfare, Public Morals and Consumer Ethics at the Bar of the WTO" fortcoming in World Trade Review, at p. 13.

24 Donald H. Regan, 'Measures with Multiple Purposes: Puzzles from EC-Seal Products', forthcoming in American Journal of International Law Unbound.

25 EC-Seals, Report of the Appellate Body, supra note 1, paras. 5.320-5.339.

26 Lorand Bartels, "The Chapeau of Article XX GATT: A New Interpretation", University of Cambridge Faculty of Law Legal Studies Research Paper Series, Paper No. 40/2014 (July 2014), pp. 7, 10-14. 
tribution points out, this supposed distinction is not without difficulty because discrimination also amounts to a restriction towards those negatively affected by it.

In the face of these difficulties with assessing the necessity of measures with multiple cost-benefit analysis, Petros Mavroidis proffers, in the words of Robert Howse, an elegant solution. Mavroidis proposes to split measures with exceptions into two and assess each one separately. The disagreement between Mavroidis and Howse centers around the question of whether the IC exception was just an illegitimate industrial policy or a legitimate human-rights purpose. Assuming Mavroidis is right, there would be no need to engage in any necessity analysis involving conflicting purposes and all problems in Seals would be solved. Assuming Howse is right, however, the question becomes whether the necessity analysis performed in relation to each of the objectives separately is capable of taking account of the fact that an alternative that is less trade restrictive but equally effective in relation to one of the policy goals nevertheless endangers the other policy goal. One way a panel or the Appellate Body could deal with this problem would be to consider that the less restrictive alternative nevertheless is not reasonably available in light of the excessive cost imposed on the other policy goal.

\section{Praxis: But which?}

One other aspect of the Seals case deserves highlighting. As Robert Howse argues in his comment and also elsewhere, the European concerns go beyond instrumental moral concerns of reducing seal suffering to include ethical-expressive elements of moral feelings, or the shocked moral conscience of Euro-

27 Robert Howse and Joanna Langille, "Permitting Pluralism: the Seal Products Dispute and Why the WTO Should Accept Trade Restrictions Justified by Noninstrumental Moral Values", 37 Yale Journal of International Law (2012), 367 et sqq. at p. 412.

28 Krista Nadakavukaren Schefer, Social Regulation in the WTO. Trade Policy and International Legal Development (Edward Elgar, 2010) at p. 5.

29 C. Foster, 'Public Opinion and the Interpretation of the World Trade Organisation's Agreement on Sanitary and PhytosanitaryMeasures', Journal of International Economic Law, 11 (2008), pp. 427 et $s q q$, passim

30 Marsha Echols, Food Safety and the WTO: The Interplay of Culture, Science and Technology (Kluwer Law International, 2001).

31 Herwig, "Zeal on Seals", supra note 23, at p. 10-11. pean consumers. ${ }^{27}$ Now, these moral feelings are of course present within the minds of people within the territorial jurisdiction of the EU and its Member States, even though the resource benefiting from the protection is located primarily outside of the EU's territory. A link with moral feelings of citizens might arguably be present in relation to a wide range of issues in risk regulation, for instance, moral disapproval of the genetic modification of organisms, of data and communication surveillance or of the impact greenhouse gas emitting countries produce on the security and livelihood of people in low-lying maritime areas. The GATT and the TBT Agreement could thus confer the possibility on WTO members to maintain what Krista Nadakavukaren Schefer calls law-enabling regulation in pursuit of collectively desirable goals that should be pursued. ${ }^{28}$

On the positive side, the acknowledgement of risk to moral feelings as a public morals issue and legitimate objective under the TBT Agreement gives due recognition to the fact that 'risk' may be more broadly construed than just a focus on casualties or disease typical in expert framings of risk. It brings to the fore the fact that risk assessment comprises a necessary political element of risk evaluation and that certain types of risky activities (for instance eating food) are imbued with ethical or expressive significance such as culture or religion. The recognition of risk to moral feeling as a potential justification for TBT measures should thus assuage those who are worried that the SPS Agreement with its focus on scientific justification and expert risk assessment has downplayed the element of risk evaluation ${ }^{29}$ and the cultural dimension of risk. ${ }^{30}$ Indeed, a WTO member could now add on extra-protections for an instrumental risk regulatory measure under, say, the SPS Agreement with a TBT justification of public morals cum moral feelings.

On the negative side, some people may pass negative evaluative judgments that others would intuitively reject (for instance, against Western democracies, Muslims or multinational corporations). If all these can become grounds for imposing trade restrictions, WTO law becomes a free-for-all. Whether public opinion and the positive law as the grounding of moral feelings accepted in Seals allows for separating the good from the bad evaluative feelings is doubtful. ${ }^{31}$

The other question is one of necessity. Which trade-impacting instruments is it reasonable to im- 
pose to satisfy those ethical-expressive feelings? As I have suggested elsewhere, ethical necessity refers to how the different virtues can be brought into mutual coherence. ${ }^{32}$ What this means is that what may be an ethically justified trade restriction on grounds of cruelty towards animals applied against a wealthy WTO member may not be one when applied against a poor WTO member because it would violate the virtue of benevolence towards that population. How such differentiation amongst WTO members can be squared with the WTO's objective of non-discrimination between WTO members is not immediately apparent.

What the Seals decision on public morals in the end exposes is that WTO law (or at least its case law) lacks a theory of the wrongfulness of risk-imposition and of the relation of different types of risk to each other. In fact, the Appellate Body in EC-Seals even admits as much because it considered that the notion of risk (to life and health) in the context of Article XX (b) is difficult to reconcile with the subject matter of protection of public morals of Article XX (a). ${ }^{33}$ It also considered that risk assessment methods lacked the usefulness for assessing risks to public morals that they enjoy for assessing risks to life and health. ${ }^{34}$ Based on that, the Appellate Body concluded that the existence of a risk to EU public morals concerns regarding seal welfare does not have to be established under Article XX (a). ${ }^{35}$ Moreover, it also stated that the treaty interpreter does not have to ascertain the exact content of the public morals standard at issue. ${ }^{36}$ This is surprising. Is it not the defendant's burden (in casu the EU) to prove that it meets the terms of the general exception in Article XX (a)? Moreover, could the treaty interpreter even sensibly apply the necessity test if it does not even know in relation to what exactly the trade measure has to be necessary?

The contrary is correct: If risk imposition is wrongful, a WTO member would ipso facto have a reason in addressing it via trade-affecting measures. If risk imposition were not wrongful there would be no corresponding reason to impose trade-affecting measures. Two examples to prove the point: Clearly, if the imported product is a carcinogen while a safe alternative is readily available, the WTO would have every right to ban it because it would be wrongful to sacrifice people uselessly. Any product always carries the risk that the consumer, upon using or consuming it, might not like it as much as she thought she would when she first purchased the product but this risk, equally clearly, cannot be an acceptable reason for banning trade because otherwise, the whole edifice of WTO law would crumble down.

How wrongfulness can be established depends on which substantive moral standard best does so, in the sense of it being free from internal contradiction and being coherent with the fundamentals of our considered normative judgment across all other cases. Several candidate morals standards are on offer. The wrongfulness of risk imposition might lie in an excess of costs over benefits that are interpersonally aggregated (as in utilitarianism or typical regulatory cost-benefit analysis), ${ }^{37}$ it might lie in an excess of expected costs over benefits that are intra-personally aggregated (deontology), ${ }^{38}$ or in moral intuitionism (in which feelings become the decisive element in grounding our moral judgments) or in what offends the practical wisdom in judgments about how to lead a good life (ethics). Such a theory of wrongfulness of risk imposition would be needed, however, not the least in order also to make sense of the concepts of the (perfect/imperfect) market, competition (and thus also of externalities) and of the types of risks which consumers implicitly must accept when they purchase foreign products, all of which undergird WTO law.

\footnotetext{
32 Ibid., at p. 19.

33 EC-Seals, Report of the Appellate Body, supra note 1, para. 5.198.

34 Ibid.

35 Ibid.

36 Ibid., para. 5.199

37 Barbara Fried, Fried, B. 2012. "Can Contractualism Save Us from Aggregation?", 16 Journal of Ethics (2012), pp. 39 et sqq., passim.

38 Aaron James, "Contractualism's (Not So) Slippery Slope". 18 Legal Theory (2012), pp. 262 et sqq., passim.
} 